\title{
PRESERVING THE POSTMEMORY OF THE GENOCIDE: THE ARMENIAN DIASPORA'S INSTITUTIONS IN PLOVDIV
}

\author{
GIUSTINA SELVELLI
}

ALPEN-ADRIA-UNIVERSITÄT KLAGENFURT

\begin{abstract}
This paper intends to shed light on the memory of the Armenian Genocide among the Armenian diaspora in Plovdiv, Bulgaria. I will focus on the patterns of promoting remembrance found in the local Armenian press and literature, on initiatives of the Armenian General Benevolent Union/Parekordzagan (AGBU) to celebrate the ninetieth and hundredth anniversaries of the Genocide, and on analyzing the cityscape of Plovdiv in terms of the monuments, the museum, and the cemetery of its Armenian community. To that end, I will employ information collected during interviews, articles from Plovdiv's main Armenian newspaper, and data I gathered while visiting the community's public spaces. I will demonstrate the importance of collective memory and remembrance of the Genocide to the preservation of the internal cohesion of the Armenian community of Plovdiv and its ethnic identity. Taking a socio-anthropological approach, I will argue that the maintenance and promotion of a specific "postmemory" of the Genocide depends heavily on the activities and initiatives of the main diaspora organization, the AGBU, on its selection of specific symbols, and on the emotional content of its communications.
\end{abstract}

Keywords: Armenian Genocide; Bulgaria; collective memory; commemorative practices; diaspora DOI: $10.14712 / 23363231.2019 .13$

Dr. Giustina Selvelli is a postdoctoral researcher at the Department of Cultural Analysis, University of Klagenfurt. Address correspondence to Universitätsstraße 65-67, 9020 Klagenfurt, Austria. E-mail: Giustina.Selvelli@aau.at. 


\section{Introduction}

In this article, I discuss the importance of the memory of the Armenian Genocide for the members of the Armenian diaspora living in the Bulgarian city of Plovdiv. I focus on the existence of an intergenerational memory of the traumatic experiences of the ancestors of those Plovdiv residents. Taking a socio-anthropological and an ethnographic approach to memory practices, I will argue that the Genocide is still an essential theme in the social, emotional and cultural life of the community, which corresponds to what Marianne Hirsch has called a "postmemory." In the context of the Armenian diaspora, the bond of individual and family memories becomes trans-generational at the moment the older generation's bond is transmitted to the next generation through collective commemoration of the cultural trauma of the Genocide. To illustrate, I will highlight the celebrations that took place at the time of the centenary of the Armenian Genocide in 2015. The celebrations were an especially symbolic event into which Armenians worldwide invested their energies and efforts. ${ }^{2}$ We witnessed increased attention to the theme of the Genocide in the press, its appearance as a debate topic during several cultural and social activities, the appearance of commemorative publications by the local Plovdiv publishing house, and more. The occasion of the centenary strengthened both intra-diasporic contacts and the Armenian community's relationship with non-Armenian groups (including Bulgarians and Turks). Widespread collective participation in acts of remembrance of the genocide enhanced the emotional bonds of the diaspora members, both locally and internationally, and increased the visibility of commemorative events. In turn, this advanced the cause of recognizing the Genocide as such and applied pressure on the Turkish government to follow suit. Remembrance activities and the display of symbols of the Genocide were common throughout the Armenian diaspora worldwide, especially in major cities such as Los Angeles, Toronto, Montreal, and Istanbul, besides of course in Armenia's capital, Yerevan. In Yerevan, delegations from nearly 60 countries attended an official ceremony of remembrance. ${ }^{3}$

1 Marianne Hirsch, “Generation of Postmemory," Poetics Today 29, No. 1 (Spring 2008): 103-128, doi: 10.1215/03335372-2007-019.

2 Sossie Kasbarian, "The Politics of Memory and Commemoration: Armenian Diasporic Reflections on 2015," Nationalities Papers 46, No. 1 (2018): 123-143, doi: 10.1080/00905992.2017.1347917.

3 Many of the commemorative events and practices have been researched by scholars of memory and the diaspora. See Kasbarian, "The Politics of Memory and Commemoration"; Duygu Gül Kaya, "Memory and Citizenship in Diaspora: Remembering the Armenian Genocide in Canada," Citizenship Studies 22, No. 4 (2018): 401-418, doi: 10.1080/13621025.2018.1462503; Duygu Gül 
In my analysis I will consider the different types of "memory sites," that is, the places where the tragedy of the past is remembered. It has been said that "in every society we can identify an array of memory sites or places of commemorative record and practice where remembrance anchors the past." These are categorized as "topographical places (archives, libraries, museums); monumental places (cemeteries, architectural edifices); symbolic places (commemorative rites, pilgrimages, emblems); functional places (manuals, autobiographies, associations); and places of power (states, elites, milieux)."

In line with this classification, I will cite as an example of a topographical place the so-called "small museum" of the Genocide in the Plovdiv church crypt; as monumental places, the town's cemetery and its monuments recalling the genocide; as symbolic places, the residents' marches in commemoration of the Genocide; and as functional places, the activities and press releases of the Armenian General Benevolent Union (AGBU), the main diaspora organization worldwide, commemorating the hundredth anniversary of the Armenian Genocide. I will omit analysis of the places of power, limiting myself to highlighting the role of the AGBU as the main philanthropic, cultural and political organ of the Armenian diaspora in Bulgaria. ${ }^{5}$

In terms of organization, Section One describes the theoretical approaches that I employed in researching Hirsch's concept of "postmemory" in the context of the inter-generational transmission of a cultural memory of the Genocide and its correlation to Assmann's distinction between communicative and cultural memory. ${ }^{6}$ Section Two outlines the history of the Armenian diaspora in Bulgaria and Plovdiv, highlighting the role of the city of Plovdiv in the peaceful

Kaya, "100 Voices after 100 years: Remembering the Armenian Genocide in Diaspora," Popular Communication 16, Vol. 2 (2018): 128-140; among others.

4 Uli Linke, "Collective Memory, Anthropology of," in the International Encyclopedia of the Social \& Behavioral Sciences, Vol. 4, ed. James D. Wright, $2^{\text {nd }}$ edition (Oxford: Elsevier, 2005), 181-187.

5 The Plovdiv Armenian community is the most important and organized Armenian community in Bulgaria, in particular because of the presence of an Armenian school and the long history of the Armenian community there, which dates back to the ninth century or earlier. The community is well integrated into the host society, and enjoys a high level of education. It contributes in quite a significant way to the socioeconomic and cultural life of the city of Plovdiv.

6 This concept has already been employed in many works dealing with the memory of the Armenian genocide. See, for example, Lisa Ann Gulesserian, “Because If the Dead Cannot Live, Neither Do We': Postmemory And Passionate Remembering in Micheline Aharonian Marcom's Armenian Genocide Trilogy" (Ph.D. dissertation, University of Texas at Austin, 2015); Derya Firat et al., "Postmemory of the Armenian Genocide: A Comparative Study of the $4^{\text {th }}$ Generation in Turkey and Armenia," Oral History/Forum d'histoire orale 37 (Special Issue on Generations and Memory: Continuity and Change) (2017), http://www.oralhistoryforum.ca/index.php/ohf /article/view/626/702. 
development of Armenian culture and institutions. In Section Three, I analyze a number of "functional places," in the form of publications commemorating the centenary of the Armenian Genocide, produced by the Plovdiv branch of the AGBU and its newspaper Parekordzagani Tzain, which include personal stories and poems on the topic. In Section Four, I continue the analysis of functional places, examining some of the publications issued by the Armenian publishing house Armen Tur, which is closely linked to the AGBU. In particular, I focus attention on the novel His Guiding Hand to Serve My People by the Armenian-Bulgarian writer Suren Vetsigian. I emphasize that novel's value as a survivor's direct testimony. Section Five deals with "symbolic places," that is, social and cultural events involving collective participation by the diaspora, such as the march held at the time of the centenary, a theater performance about the Genocide, and a public reading of excerpts from novels by Armenian authors. In Section Six, I devote attention to the "Turkish factor," the question of recognition of the Armenian genocide by the Turkish government, and the legacy of Turkish-Armenian journalist Hrank Dink for Armenian and Bulgarian audiences. In Section Seven, I describe examples of "monumental" places of memory, such as Plovdiv's Armenian cemetery and its local monuments, including a khachkar (an Armenian cross-stone) dedicated to the Genocide. In Section Eight, I focus on a "topographical" place, the "small museum" of the Genocide, which is filled with objects carried by survivors as they escaped into Bulgaria from Ottoman territory. Finally, in the last section before the conclusion, Section Nine, I discuss the importance of the "imaginary" factor, the role of personal imaginations of the lost territory of the ancestral Armenian homeland as a specific factor that encourages a relationship between the Armenian community in Plovdiv and present-day Turkey and the independent Republic of Armenia.

\section{The Postmemory of the Armenian Genocide}

In considering the patterns that perpetuate the memory of the Genocide in Armenian communities around the world, it is important to remember that official commemorations of the Genocide have only taken place since the fiftieth anniversary of the event, that is, since 1965 . Nevertheless, the memory of the Genocide affected the diaspora long before that date. The political context (including limitations on minorities' freedom of expression imposed by the Soviet Union) and practical and psychological factors (such as the concentration of the worldwide diaspora's energies and resources on their integration into their host countries) inhibited public discussion of the topic. 
Since the fiftieth anniversary, the survivors of the Genocide, together with their children and grandchildren, have finally been able to break down the "wall of silence" that blocked the expression of their memories in the previous decades. That is why, after half a century, many young Armenians became more engaged in political activities and demonstrations, after being exposed in an "intergenerational way" to a cultural trauma that left "indelible marks upon their group consciousness, marking their memories forever, and changing their future identity in fundamental and irrevocable ways."7 Since 2015, the specific "pattern of functioning" of the Armenian diaspora has become rooted in its continuous engagement with the trauma of the 1915 Genocide. According to the famous Romanian-Armenian writer Varujan Vosganian, the author of the novel The Book of Whispers, memory has become for the Armenians "more important than both death and life."

More than one hundred years after the tragic events of 1915, and after the 2015 centenary that was a symbolic moment of unity and of remembrance of the Genocide worldwide, it is appropriate to ask ourselves how the memory of the Genocide is being carried on by later generations, the children and grandchildren of the descendants of the survivors. In this respect, the concept of the "generation of postmemory," elaborated by Marianne Hirsch, is helpful. In her work, Hirsch used that term to refer to the generation that follows the one that experiences a trauma. She describes the second generation's relationship to the tragic events witnessed by their parents as a deep and emotional experience for them as well, which constitutes a memory in its own right. ${ }^{9}$

However, in the case of the Armenian Genocide, the memory extends far beyond the first generation of survivors' descendants, which proves that family memory can be reproduced and transmitted into the minds and hearts of much later generations. In my view, this is possible because of the persistence of individual stories, images, and narratives, not only within the family setting but also through "affiliative" forms of postmemory ${ }^{10}$ and more "institutionalized," exteriorized examples of cultural memory. ${ }^{11}$ The AGBU contributes in a major way

7 Richard G. Hovannisian, “The Armenian Genocide and Patterns of Denial," in The Armenian Genocide in Perspective. Cultural and Ethical Legacies, ed. Richard G. Hovannisian (New Brunswick, NJ: Transaction Books, 1986), 111-133, here 113.

8 David Gaunt, “'Memory is More Important Than Death and Life': 100 Years After the Armenian Genocide”, Baltic Worlds 7, No. 2-3 (September 2014): 9-11.

9 Hirsch, "Generation of Postmemory," 105-107.

10 Ibid., 115.

11 Jan Assmann, "Communicative and Cultural Memory," in Cultural Memory Studies: An International and Interdisciplinary Handbook, ed. Astrid Erll and Ansgar Nünning (Berlin: De Gruyter, 2008), 109-118. 
to that process. ${ }^{12}$ This transnational diasporic organization, founded in Cairo in 1906 , and present on Bulgarian territory since 1910, operates in close cooperation with the Armenian Apostolic Church. Its Bulgarian branch holds an open dialogue and maintains strong ties with AGBU branches all over the world. ${ }^{13}$ The AGBU's headquarters are in New York, and it is present in 23 countries of the diaspora. In promoting discourse and memory practices of the Genocide among the Armenian diaspora in Plovdiv, the AGBU has a dual role, one that is at once political (collective representation of the Armenian community) and spiritual (linked to the authority of the Armenian Apostolic Church). ${ }^{14}$ The AGBU stands out as the main actor capable of channeling an intergenerational, collective trauma. It actively works to transform family experiences and traumas into a transgenerational form of memory, embedded in a shared symbolic system of signification and in a powerful "collective imaginary."

The work of the AGBU allows the later descendants of survivors to connect deeply to the injustices suffered by their ancestors, and to fully identify with their suffering. This connection is strengthened by the ongoing refusal of the Turkish authorities and the majority of Turkish public opinion to recognize the reality of the Genocide. The activity and the discourse supported by the AGBU and its representatives increase the internal cohesion of the Armenian community and promote the preservation of its memory of the Genocide. This implies the acceptance by the community of a symbolic frame, ${ }^{15}$ a sort of national aware-

12 The president of this non-profit organization in Plovdiv is Rupen Tchavushian. Its members (including the journalists of the AGBU bulletin, Parekordzagani Tzain) work on a voluntary basis. The AGBU is aligned politically with the Armenian political party Ramgavar (the Armenian Democratic Liberal Party), which holds liberal, free-market views, unlike the Dashnaktsutiun party (the Armenian Revolutionary Federation) whose leftist orientation is represented in Plovdiv by the "rival" Armenian newspaper Vahan. See Giustina Selvelli, "The Role of the Newspaper Parekordzagani Tzain and its Related Institutions in the Preservation of Language and Identity in the Armenian Community of Plovdiv," Bulletin of Transylvania University of Braşov (Series IV - Philology and Cultural Studies) Vol. 11 (60), No. 1 (2018): 199-222.

13 The AGBU was abolished during the 45 years of communist rule in Bulgaria and was replaced by the Yerevan Association. It re-started its activities in 1991. Surprisingly, Bulgaria is now the country of the world with the second highest number of AGBU branch offices (after the United States), which are located in the cities of Burgas, Dobrich, Haskovo, Plovdiv, Ruse, Silistra, Sliven, Sofia, Varna, and Yambol.

14 Another diaspora organization present in Plovdiv is the philanthropic and humanitarian Armenian Relief Society (H.O.M.), which nevertheless plays a marginal role compared to the powerful AGBU. For Armenian diaspora institutions worldwide, see Khachig Tölölyan, "Elites and Institutions in the Armenian Transnation," Diaspora: A Journal of Transnational Studies 9, No. 1 (Spring 2000), 107-136, doi: 10.1353/dsp.2000.0004.

15 Anthony D. Smith, Ethno-Symbolism and Nationalism: A Cultural Approach (London: Routledge, 2009). 
ness that is activated on specific occasions for interaction between the members of the community. Commemorations are a necessary component of Armenian life, in the absence of which the acts of the perpetrators of genocide would be legitimated. Armenians "who want to be ethical, are, so to say, doomed to commemorate," to such an extent that the survivors' descendants have a particular "post-genocide mode of being." 16

To analyze the complex phenomenon of the remembrance of the Armenian Genocide, I will employ a combination of sociological, anthropological and ethnographic approaches. The first approach is derived from theories about the sociology of collective memory introduced by Pierre Nora, ${ }^{17}$ and then elaborated by Marianne Hirsch, ${ }^{18}$ and Eviatar Zerubavel. ${ }^{19}$ These theories take into consideration the importance of the discourse, practices and sites around which and through which memory is affirmed and made present as a tool to strengthen the bonds of a social collectivity. The anthropological approach affirms the importance of symbols and rituals in the construction and maintenance of national and ethnic identities. ${ }^{20}$ It underlines the role of emotions in the creation of cultures and memories. ${ }^{21}$ The ethnographic approach makes use of observations of study participants and the space they inhabit, as well as a specific form of textual analysis, which I call the "ethnography of text." This third approach is drawn from "Writing Culture," as described by James Clifford and George E. Marcus. ${ }^{22}$ It takes into consideration written sources produced by the community itself on a particular topic, with attention to the ways that discourse is produced by different actors and what the culture wants to say about itself. From this point of view, not only articles published by the AGBU's newspaper are useful, but so are the inscriptions on the monuments in the public space in Plovdiv. I have observed both for an extended, "iterative" period of time, spanning more than

16 Serafim Seppälä, "The 'Temple of Non-Being' at Tsitsernakaberd and Remembrance of the Armenian Genocide: An Interpretation," Approaching Religion 6, No. 2 (2016): 26-39, doi: 10.30664/ar.67589.

17 Pierre Nora, ed., Les Lieux de mémoire, Vol. I (Paris: Gallimard, 1997 [1984]).

18 Hirsch, "Generation of Postmemory."

19 Eviatar Zerubavel, Time Maps: Collective Memory and the Social Shape of the Past (Chicago: University of Chicago Press, 2004).

20 See Benedict Anderson, Imagined Communities: Reflections on the Origin and Spread of Nationalism (London: Verso, 1983); Anthony P. Cohen, Symbolic Construction of Community (London: Tavistock, 1985).

21 Renato Rosaldo, Culture \& Truths: The Remaking of Social Analysis (Boston: Beacon Press, 1993).

22 James Clifford and George E. Marcus, eds., Writing Culture: The Poetics and Politics of Ethnography (Berkeley, CA: University of California Press, 1986). 
eight years. ${ }^{23}$ My contribution to the remembrance of the Genocide relies on different sources and varying levels of analysis in order to document how the discourse of the Genocide is constructed.

\section{The Armenian Genocide and the Diaspora in Bulgaria}

For Armenian official historiography, based on collective as well as personal narratives, the watershed in recent Armenian history is the tragic persecution of the Armenians in the last years of the Ottoman Empire, which began with the so-called "Hamidian Massacres" in 1894-1896. ${ }^{24}$ The 1915-1918 Genocide counted up to 1.5 million Armenian victims. In the years between 1922 and 1926, hundreds of thousands of Armenians left the Turkish territories and formed a worldwide diaspora. After Emperor Boris III of Bulgaria decided to open his country's borders to them, tens of thousands of Armenians arrived in neighboring Bulgaria. They settled especially in the city of Plovdiv. ${ }^{25}$ While some of them continued on to destinations such as France, the United States, and Canada, others remained in Plovdiv to start a new life.

With the influx of new refugees, Plovdiv confirmed its multiethnic urban character. ${ }^{26}$ The city was fertile ground for the development of important cultural institutions that preserve to this day the ethnolinguistic identity of Armenians, who have been present in Bulgaria since very early times. ${ }^{27}$ Bulgaria achieved autonomy within the Ottoman Empire as early as 1876 and had offered shelter to its Armenian community since the time of the Hamidian persecutions. A rhetoric and discourse of interethnic solidarity emerged at that time, ${ }^{28}$ fostered by

23 My first contact with the Armenian diaspora of Plovdiv dates back to 2010, when I spent one year of fieldwork with the community as I prepared my Master's thesis. My work has been uninterrupted since then, thanks to my frequent stays in the city in the following years, my personal and professional relationships with various members of the community, and my reading of its publications, mainly the newspaper Parekordzagani Tzain and books issued by the local publishing house, Armen Tur.

24 Boris Adjemian and Mikaël Nichanian, "Repenser les 'massacres hamidiens': la question du precedent,” in Études armeniennes contemporaines, No. 10 (2018): 7-18, doi: 10.4000/eac.1385.

25 Evgeniya Mitseva, Armentsite v Bŭlgariia - Kultura i identičnost (Sofia: IMIR, 2001), 18.

26 Angel Wagenstein, Dalech ot Toledo. Avram Kŭrkacha (Sofia: Colibrì, 2002).

27 See Dimitra Aslanian, Storia della Bulgaria dall'antichità ai giorni nostri (Milano: La Casa di Matriona, 2007); Janet Hamilton and Bernard Hamilton, Christian Dualist Heresies in the Byzantine World, c.650-c.1450 (Manchester: Manchester University Press, 1998), 71-75. An Armenian school (Tiutiundjian) was founded in 1834, and several Armenian periodicals had seen the light of day as early as the second part of the nineteenth century.

28 Stepan A. Agukian, Otzvutsite na Armenskiia Genotsid v Bŭlgarskiia Pechat (Sofia: Publication of the National Committee "80 Years from the Armenian Genocide," 1995). 
the fact that the Bulgarians had themselves been victims of Ottoman violence (as in the case of the famous "Bulgarian horrors" committed by the Turks, which were reported to the Western world in the 1870s). ${ }^{29}$ The difficult common situation of the Christian subjects of the Ottoman Empire for more than 400 years contributed to the Bulgarians' solidarity and empathy towards the Armenian population, whom they perceived as innocent victims of an "Oriental" injustice that continues to this very day. In Bulgaria, Armenians always stood out as a particularly educated and skilled community, whose members were active as merchants, craftsmen, doctors, jewelers, etc. and occupied a prominent role in the host society. It is not surprising that the institutional discourse of the Armenian diaspora flourished in Plovdiv, given that Bulgaria's policies, practices and ideology were particularly sensitive to the welfare of this community.

Already by the 1890s, the Bulgarian press was publishing articles about the most important events in the country's Armenian colony, informing Bulgarians about the customs and traditions of the Armenian community, praising its refined, ancient culture and utilizing a discourse of solidarity. For example, in 1881 the local newspaper Maritsa wrote: "The Armenians have never been our opponents; on the contrary, we have continually received moral support from their press and their influential media." Similarly, Plovdiv's Bulgarian-language newspaper commented in 1890 that the Armenian nation, despite several attempts at its annihilation and assimilation, had managed to survive and keep its identity alive, "when instead many neighboring nations, incomparably stronger...have disappeared from the face of the earth." After the first massacres involving thousands of Armenians took place in the mid-1890s on Ottoman soil, the Bulgarian press wrote several articles about the crimes, affirming that "these new, horrendous crimes, worse than the previous ones, have come to show us what an Asian government is capable of, a savage sultan."30

Similar manifestations of solidarity emerged after the genocide. ${ }^{31}$ Photos and articles mentioned in a brochure published by Stepan Agukian for the

29 Marco Dogo, Storie Balcaniche. Popoli e Stati nella transizione alla modernità (Gorizia: Casa Editrice Goriziana, 1999), 50.

30 All quotes are from Hripsime Erniasian, "90 godini ot armenskiia genotsid. Chronika na otzivite ot sŭbitieto,” Parekordzagani Tzain, No. 65 (April 2005).

31 When referring to the intercultural contacts between the two countries, we cannot forget the famous "Armentsi" poem written at the beginning of the twentieth century by Peyo Yavorov, one of the most famous Bulgarian poets, to honor the Armenian victims of the Hamidian persecutions of the late 1800s. The poem is a moving example of Armenian-Bulgarian brotherhood, which remains carved into the consciousness of both peoples. From their side, the Armenians have expressed their gratitude to their adoptive country in a variety of ways in the course of 
eightieth anniversary of the Armenian genocide in 1995 testify to how Bulgarian newspapers helped to increase the awareness of the general public of the persecutions against Armenians in the collapsing Ottoman Empire. ${ }^{32}$ More than a century after those tragic events, it is extremely important for Armenians to know that the fate of their ancestors has found sympathy and resonance in the newspapers of the country which has become their second homeland. Any word written on this topic is received as a sign of support for their community and recognition of the Genocide of which their people were victims. It is concrete proof of a historical truth that cannot be erased. It is no coincidence that Turkish authorities have tried to destroy the evidence of their crimes by eliminating any written testimony or archived text about the horrors that were committed, together with any trace of Armenian cultural heritage in the areas from which the Armenian population was cruelly and tragically expunged. The erasure of the thousand-year history and the cultural presence of the Armenian people in the former Ottoman territories, together with Turkey's official denial of the Genocide, is a source of deep feelings of injustice for Armenians, which still continue to be experienced with intense frustration. ${ }^{33}$

\section{The Armenian Genocide in the Newspaper Parekordzagani Tzain}

At the time of the Genocide, not only Bulgarian newspapers devoted attention to it. So did the Armenian press, which had been active in Bulgaria since the second half of the nineteenth century. ${ }^{34}$ Nowadays, the affairs of the Armenian community in Plovdiv are covered by the biweekly Parekordzagani Tzain, published by the charitable association AGBU since 2004. The topic of the Genocide is a recurrent one in the pages of this newspaper. The reporting is especially transnational in scope because of the relationships among the diaspora communities in different countries (above all Romania, Turkey, the United States, and

the last century. One example is a short video released in 2018 in various media, in which the Bulgarian Armenians turned to their "adoptive" Balkan country, declaring profound gratitude for its hospitality and solidarity. See "Bŭlgarskite armentsi blagodarikha na rodinata si Bŭlgariia (video)," 0:01:12, April 24, 2018, https://www.blitz.bg/obshtestvo/blgarskite-armentsi-blagodarikha-na-rodinata-si-blgariya-video_news595707.html.

32 Agukian, Otzvutsite na Armenskiia Genotsid.

33 See Aldo Ferrari, "Viaggio nei luoghi della memoria armena in Turchia e Azerbaigian," LEA Lingue e letterature d'Oriente e d'Occidente 5 (2016): 179-192, here 185, doi: 10.13128/LEA-1824$484 \mathrm{x}-20031$.

34 Garo Hayrabedian, "Armenskiiat periodichen pechat v Bŭlgariia," Bŭlgarska Etnografiia, No. 3-4 (1994): 105. 
Canada) and with the Republic of Armenia, which has established a government ministry for the diaspora. ${ }^{35}$ In political terms, the difficult issue of the relationship with Turkey and its denial of the Genocide is very present in the discussions of Plovdiv's intellectuals and community representatives. It is particularly evident in the pages of the local press, although the tone of the reporting started to change after $2015 .^{36}$

In comparison with the other local Armenian publication, Vahan, ${ }^{37}$ Parekordzagani Tzain focuses less on contemporary political issues. Rather, it reports on events in the Armenian communities of Plovdiv and other Bulgarian cities, and on the many social and cultural activities of the AGBU around the world. Since its founding, Parekordzagani Tzain has been the main channel for promoting and sharing initiatives and commemorations of the Genocide with the Plovdiv community. It also contributes to organizing fundraising activities aimed at erecting monuments dedicated to Genocide victims and mobilizing resources for practical initiatives, as in the following announcement from 2015:

On April 24th, we will mark 100 years since the Genocide against the Armenians! In connection with this, we are collecting the means to mark this tragic anniversary, which we will express through various informative tools - billboards, banners, posters and more. We encourage in the sincerest way anyone interested in supporting this noble initiative according to his or her possibilities. ${ }^{38}$

On this occasion, the AGBU branch in Plovdiv promoted display of the "forget-me-not" flower, a symbol that was chosen as a sign of remembrance of the Genocide by the diaspora worldwide. The following sentences appeared along with the flower: "I remember and condemn. I remember and I demand. I live and I remember. I live and I demand." The display of the forget-me-not confirms that the Armenian diaspora's existence is ontologically dependent on the

35 Khachig Tölölyan and Taline Papazian, "Armenian Diasporas and Armenia: Issues of Identity and Mobilization," Études armeniennes contemporaines, No. 3 (2014): 83-101.

36 Many Armenians now feel that there is a need to focus on topics other than the Genocide, in order not to be "stuck in the past," in a "victim mentality."

37 Vahan has been issued since 1991, on a weekly basis.

38 Original in Bulgarian: “Скъпи сънародици, На 24 април тази година, се навършват 100 години от Геноцида над арменците! Във връзка с това, набираме средства за отбелязване на тази трагична годишнина, която ще изразим чрез различни информационни средства билбордове, транспаранти, плакати и други. Молим найучтиво, всички желаещи, според своите възможности, да подпомогнат това благородно начинание.” The announcement appeared in Parekordzagani Tzain, No. 147 ( January 2015). 
memory of its past, that is, on remembrance of the sufferings and tragedy experienced by its ancestors.

Among the many initiatives to commemorate the events of 1915-1918, a competition was launched in the pages of Parekordzagani Tzain in early 2015. Its aim was to confer an award on a text (a piece of prose, an essay, a poem, or a dramaturgical work) written on the theme of the hundredth anniversary of the Genocide. As a result, several poems were published in issue 152 of the newspaper. ${ }^{39}$ They are all in the Bulgarian language and were written by Plovdiv citizens (probably all of them of Armenian origin, although we cannot state that with certainty) as well as by authors from other Bulgarian cities. Among them, we find an extremely touching poem written by a 14-year-old girl of Armenian ancestry from Plovdiv, whose name is Vartuhi Erdeklian. The title of the composition is "Pomnia" ("I Remember"):

And how many Armenians were not born?

Wanderers tossed away in foreign worlds

Starting over from scratch, on their way they marched

creating our forefathers, up to what we are now

Today - now we are here

The resettlers from the genocide survivors

One to the East, the other to the West

The heirs of those who chose to live

Nobody dies after his death

As long as the memory remains with the living ones

As long as somebody wakes up with his name

And goes to sleep with a smile for his deeds

From my eyes tears flow

... Tears of joy they are

Because I know who were my ancestors

And I remember ... And do you remember too $?^{40}$

39 Parekordzagani Tzain, No. 152 (May 2015).

40 “А колко арменци се не родиха? / Скиталци захвърлени в чужди светове / Започвайки от нула по своя път пробиха / Предците ни до това което сме. // Днес - сега сме ние тук / На спасените от геноцида преселници / Един на изток, на запад - друг / Избрали живота наследници. // Никой след смъртта се не умира / Щом спомена със живите е / Щом някой 
This poem manifests quite explicitly the intergenerational transmission of the trauma, the creative force of "postmemory" in later generations, and the relevance of "affiliative" acts carried out by institutions that are aimed at the "re-individualization" of cultural memory. ${ }^{41}$ A 14 -year old girl is likely to be no less than a great-grandchild of a Genocide survivor, but this does not imply that her experience of postmemory is less intense than that of the generations preceding her. Her composition is also evidence that, although Armenians around the world are divided in many ways, there is one thing that unites them: the goal of keeping alive the memory of the catastrophe that traumatized their families. ${ }^{42}$

The fact that this text was published along with many others in the pages of Parekordzagani Tzain also proves the extent to which a "communicative memory" handed down privately through the generations can be transformed into a "cultural memory." 43 Armenians take advantage of "institutional" channels to create images, monuments, and other forms of commemoration that express the communal, shared identity of the diaspora. I believe that with regard to the memory of the genocide in the Armenian community, the border between individual and collective suffering is quite blurred. In the year 2015, an increasing number of articles were published in Parekordzagani Tzain that were devoted to the memories and personal stories of the descendants of Genocide survivors.

An example of this is a text that appeared in issue 151 of the newspaper with the title "Memories of Haiganush: A Story of the Fate of My Parents During the Armenian Genocide (1915-1922)," written by Haiganush Dzhezarlian. In her article, the author recalls the life of her parents in the city of Van, their daily activities and their contacts with other communities such as Kurds and Turks before the genocide. She then recounts the terrible vicissitudes her mother and father experienced before they managed to settle and find refuge in the Bulgarian city of Varna. The story is written in a lucid and quite essentialist way, but nonetheless, as a personal narrative, it has the power to involve the reader in a touching, emotional family story. An important fact is that this private, individual story is connected to the general history and fate of the Armenian nation, which allows it to channel a flow of empathy, participation, and identification. All Armenians can identify themselves with such tragic narratives. When they

се буди със неговото име / И с усмиква за делата му заспива. // От очите ми бликват сълзи /...сълзи на щастие са те / Защото знам какви са моите предци / И помня... а помниш ли и ти?” Author's translation - G. S.

41 Hirsch, "Generation of Postmemory," 115.

42 See Gaunt, "'Memory is More Important than Death and Life," 10.

43 Assmann, "Communicative and Cultural Memory." 
are published, the sense of community is affirmed and strengthened. That sense becomes a valuable tool for soothing the wounds and traumas of the inter-generational experience of the Genocide. At the same time, the memories recall vanished traces of a lost homeland: the territory and cultural coordinates of historical Armenia, or "Western Armenia," where the city of Van on the shores of Lake Van occupied a special place.

\section{AGBU Publishing Activities}

AGBU's publishing house, Armen Tur, is aimed at promoting the works of Armenian literature in Bulgaria. It plays a fundamental role in the commemoration of the Genocide and assists in creating a shared national and cultural memory. The publishing house and its promotion of Armenian literature predate the founding of the newspaper itself, having been established around the end of the 1990s. Among the books it has published are important literary works related to the Genocide, such as a novel by Soviet Armenian writer Khachik Dashtents (1910-1974), which appeared in Bulgarian in 2003 under the title Zovŭt na orachite (Call of Plowmen), ${ }^{44}$ and one by Suren Vetsigian (1905-1961), Voden ot Boga $v$ sluzhba na naroda si (His Guiding Hand to Serve My People), published in $2001 .{ }^{45}$

Both authors were born within the borders of the Ottoman Empire, in so-called Western Armenia (which corresponds geographically to the Eastern part of Turkey). In both novels, they share their personal experiences during the tragic years of the genocide. After escaping the massacres, Dashtents spent the rest of his life in Soviet Armenia. Vetsigian lived in Greece, Bulgaria and the United States, and eventually returned to settle in Plovdiv, in the country that had first granted him asylum. Vetsigian became a prominent member of the local Armenian community in Plovdiv. He was the director of the Armenian school, as well as a journalist and writer. Furthermore, he used his experience as a survivor of the Genocide to inspire his mission of nurturing and preserving a sense of "Armenianness" among members of the diaspora.

In the preface to his novel, Vetsigian says that he wrote it in the hope that it would contribute to shedding light on the story of a "near, unlucky nation." His motivation was to inform about the historical truth of what happened to the Armenian people during the last years of the Ottoman Empire and to give

44 Khachik Dashtents, Zovŭt na orachite (Plovdiv: Armen Tur, 2003).

45 Suren Vetsigian, Voden ot Boga v sluzhba na naroda si (Plovdiv: Armen Tur, 2001). 
a response to books written by the Turks that provide a distorted view of historical events. Vetsigian was still a boy when the massacres occurred in his native town of Shabin Karahisar. He resisted his adverse circumstances with extraordinary strength. In his novel, the emotions of a teenager, who is catapulted from one place to another after surviving a genocide in which he lost everything and everyone, are portrayed sympathetically when he comes into contact with the symbolically strong elements of Armenian culture. For example, at a certain point he finds himself in an old Armenian monastery holding in his hands an ancient Armenian manuscript. Fourteen years after its first appearance, the Armen Tur publishing house issued an English translation of the book. In fact, the author had originally written the book in English, and the AGBU of Plovdiv decided to make it available for the first time in a digital format online. ${ }^{46}$

This publishing initiative was linked to the commemorations of the hundredth anniversary of the Armenian Genocide of 1915 and was aimed at reaching a wider audience and giving visibility to an important work that has not received the consideration it deserves. In the AGBU's vision, when one remembers the victims of the genocide one should not forget the memory of those who organized active resistance, as in the case of the town of Shabin Karahisar, as described in Vetsigian's novel. ${ }^{47}$ Vetsigian enriches his narrative of the tragic events with historical facts that reveal Armenians to be not only victims, but also fighters.

In addition to the English translation of Vetsigian's novel, another book was published to coincide with the hundredth anniversary, a Bulgarian translation of the novel Among the Ruins (Sred Razvalinite) by Zabel Yesayan. This work deals with the massacres of Armenians in the Anatolian city of Adana in 1909, which the author herself witnessed. It documents the destructiveness of the pogroms waged against the defenseless Armenian population, in what was a prelude to the genocide carried out by the Young Turks. Yesayan herself was persecuted and was the only woman among the Armenian intellectuals who were deported from Istanbul to Anatolia on April 24, 1915 at the beginning of the Genocide. She was able to escape and fled first to Bulgaria and then to the Caucasus, where she worked with other refugees who had survived the massacres. She continued to document the consequences of the persecution of the Armenians.

46 Souren M. Vetsigian, Autobiography: His Guiding Hand to Serve My People (Plovdiv: Armen Tur, 2014). The book is available to read at http://issuu.com/agbuplovdiv/docs/souren_vetsigian.

47 See Donald Bloxham, "Determinants of the Armenian Genocide," in Looking Backward, Moving Forward: Confronting the Armenian Genocide, ed. Richard G. Hovannisian (New Brunswick: Transaction Publishers, 2003), 43. 
While narrating the tragic events of the genocide, all these novels describe the Armenian component of the Ottoman cultural landscape, reconstructing the patterns of existence of a past world that has been totally wiped out in those territories. Similar to what has been said about Jewish narratives about their lost homelands in Europe, this literature not only preserves the image of past circumstances in a nostalgic way, it brings them into the present and "gives them cultural significance well beyond that of historically concrete sites." 48 As a consequence, we can see that "myths emerge almost naturally here, as the sense of loss acquires permanence." ${ }^{49}$ Obviously, myths are not the same as "invented stories" but rather are images, words and narratives capable of evoking more than just bare facts. They have symbolic strength themselves and generate a potentiated imaginary of the past. The bitter history of the lost ancestral territories of the Armenians has turned into a myth for the Armenian people. It is "remembered, narrated, and used, that is, woven into the fabric of the present." 50 That is the reason why these narratives are a proper object of socio-anthropological investigation. In the collective memory of the Armenian people, they have acquired a value beyond mere historiography. The AGBU's publishing and promoting of these literary works is connected to a desire to transmit the cultural and identitarian memory of the Genocide in line with its mission of perpetuating "postmemory" among future generations of Armenians in the diaspora.

\section{The Commemoration of the Armenian Genocide in Plovdiv}

Commemorations of the Genocide take place on April 24, the day of the first organized deportation in 1915 of the Armenian intellectual class from what was then known as Constantinople to the city of Ankara. This deportation was the prelude to large-scale massacres of nearly the entire Armenian population. ${ }^{51}$ The main strategist behind the persecution of the Armenians was the Ottoman Minister of the Interior, Talaat Pasha, who was a member of the movement of the Young Turks. ${ }^{52}$ The Armenian massacres have been recognized as genocide by twenty-nine countries, as well as by various international organizations and

48 Iwona Irwin Zarecka, Frames of Remembrance: The Dynamics of Collective Memory (New Jersey: Transaction Publishers, 1994), 92.

49 Ibid.

50 Jan Assmann, Moses the Egyptian: The Memory of Egypt in Western Monotheism (Cambridge: Harvard University Press, 1997), 9-10.

51 Raymond Kévorkian, The Armenian Genocide. A Complete History (London: Tauris, 2006), 251.

52 George Deukmejian, "Introduction," in The Armenian Genocide: History, Politics, Ethics, ed. Richard G. Hovannisian (Basinstoke: Macmillian, 1992), XII. 
institutions including the United Nations (1985) and the Council of Europe (2001). In 2015, concurrently with the centenary of the beginning of the persecutions, the Bulgarian Parliament adopted a declaration recognizing the events, although it called them not genocide but the "mass extermination of the Armenian people in the Ottoman Empire." 53 However, for a number of years, the municipalities of Plovdiv, Burgas, Ruse, Stara Zagora and Pazardzhik have officially recognized the Armenian massacres as a "genocide," a fact that has led in some cases to tensions in Bulgaria's relations with Turkey. ${ }^{54}$

Plovdiv is a city that is particularly sensitive to Armenian history, since it is home to the largest Armenian community in Bulgaria, which numbers about 4000 people out of a total population of 12,000 , as estimated in official figures. It is therefore not surprising that the celebrations on April 24 are always marked by wide participation and great emotion. ${ }^{55}$ The day usually begins with a memorial mass in the Surp Kevork Apostolic Armenian Church, followed by a few minutes of silence in front of the large wooden cross (khachkar) located in the courtyard of the community complex, between the church and the Armenian school that bears the name of Viktoria and Krikor Tiutiundjian. Pupils usually recite poems dedicated to their ancestors who perished in the genocide and honor the victims by placing flowers around the monument. Then, in the afternoon, members of the Armenian community and representatives of local Armenian organizations march, together with Bulgarians, down the main street of the city waving the Armenian and Bulgarian flags. The march ends in Plovdiv's central square where a statement is read, in which Turkey is urged to acknowledge that the crimes perpetrated against Armenians during the First World War were a genocide. ${ }^{56}$ As is well known, the essence of commemoration is participation, the coming

53 On this occasion, Prime Minister Boyko Borisov wanted to use the Bulgarian term for "genocide," but his ultimate declaration did not satisfy those who hoped for unequivocal recognition at the international level. An article, "Parliament Passes Resolution on Armenians' Mass Extermination in the Ottoman Empire in the 1915-1922 Period," appeared on the website of the Bulgarian News Agency, April 24, 2015, http://www.bta.bg/en/c/DF/id/1065011.

54 An example of this is the suspension of a project to establish a low-cost airline link between Plovdiv and the city of Bursa in Turkey following the recognition of the Armenian genocide by Plovdiv's municipal council. See Atanas Tsenov, "European Projects in Bulgaria Fail Because of a Dispute with Turkey About the Armenian Genocide," Radio Bulgaria, March 17, 2016, http://bnr .bg/en/post/100670478/european-projects-in-bulgaria-fail-because-of-a-dispute-with-turkey -about-the-armenian-genocide.

55 Commemorations also take place in some of the other major cities of the country including Sofia, Varna, Silistra, Ruse, and Pleven.

56 In 2018, the day ended with the screening of the recent documentary on the Armenian genocide, entitled "Izkoreniavane" ("Extirpation"). The film was made by a Bulgarian director, Kostadin Bonev, in 2017. It was screened simultaneously in Plovdiv and in several other Bulgarian cities. See 
together of people to honor the subject of commemoration. ${ }^{57}$ The annual march on April 24 supports a true lieu de mémoire, in that it is intended to affirm a specific memory, ${ }^{58}$ and is a symbolic practice displaying the unity and continuity of the community. As previously mentioned, in 2015 the weeks leading up to April 24 were filled with news about initiatives linked to the commemoration of the genocide.

One such initiative was a theater piece directed by Evelina Nikolova and performed by the Armenian children's theater school of Plovdiv, which was based on Vosganian's The Book of Whispers. The stage for this cultural event was Plovdiv's well-known Kuklen Teatar. A very responsive and emotional audience filled the hall. The emotion was particularly evident when the orchestra played a famous song, "Dle Yaman," which was collected and arranged by the famous Armenian priest and musicologist, Komitas. Based on the folkloric tradition of ancient Armenia, this song has become a hymn and a symbol of the Genocide among the diaspora. Rubie Watson says that remembrance is constructed when the members of a community share "sets of images that have been passed down to them through the media of memory through paintings, architecture, monuments, ritual, storytelling, poetry, music, photos, and film." ${ }^{9}$ "Dle Yaman" stands out as one of the most powerful tools of remembrance of the Armenians' tragic past. It is closely connected to the sad fate of Komitas (or Gomidas in the Western Armenian pronunciation), who fell victim to the Turkish persecutions. Although he survived physically, he suffered from severe psychiatric problems for the rest of his life.

The children of the Malvina Manukian theater school, ${ }^{60}$ which is supported by the Plovdiv AGBU, rehearsed their roles in the theatrical version of The Book of Whispers for months. In so doing, the children became familiar with the horror of the Genocide. They internalized it to the extent that they gave an impeccable performance before their audience. The eager participation by young Armenians in this commemoration of the traumatic events of the past proves that the

YouTube video, 0:05:01, posted by Kostadin Bonev, September 16, 2017, https://www.youtube .com/watch? $\mathrm{v}=\mathrm{dKqxpSAZJvM.}$

57 Edward S. Casey, Remembering: A Phenomenological Study (Bloomington: Indiana University Press, 1987).

58 “Les lieux de mémoire naissent et vivent du sentiment qu'il n’y a pas de mémoire spontanée, qu’il faut créer des archives, qu'il faut maintenir des anniversaires, organiser des célébrations...parce que ces opérations ne sont pas naturelles," in Nora, ed., Les Lieux de mémoire, Vol. I., p. 29.

59 Rubie S. Watson, "Memory, History and Opposition: Under State Socialism. An Introduction," in Memory, History and Opposition: Under State Socialism, ed. Rubie S. Watson (Santa Fe: School of American Research Press, 1999), 1-20, here 8.

60 The theater school was founded by a former teacher of the Armenian School in Plovdiv, Malvina Manukian. 
descendants of genocide survivors experience a form of "postmemory," linked to an "obligation that was placed upon them to be the bearers of hopes and aspirations of a whole people." 61 The narrative of the Genocide and the struggle for its recognition is being transmitted directly to a new generation, but also to an external audience, whose approbation is needed in order to legitimate the new generation's efforts to remember.

Another fact that can be gleaned from articles in Parekordzagani Tzain about the commemoration of the Genocide is the Plovdiv community's links with the initiatives of other diaspora communities. Those links are maintained and made visible through a dense network of cooperation. One significant initiative at the European level in 2015 was the so-called "Armenian Genocide Worldwide Reading" which took place in several cities on April 21. The Reading was organized by the International Literature Festival in Berlin in order to sensitize a European audience to a topic that is still alive and hotly debated. In Plovdiv, the Reading took place at the Ethnographic Museum. It included excerpts from the novels of Romanian-Armenian, Soviet Armenian and Bulgarian-Armenian authors, such as Vosganian's The Book of Whispers and works by Kachik Dashtents and Suren Vetsigian.

\section{The Turkish Factor in the Armenian-Bulgarian Relationship}

With its connections to the AGBU's worldwide structure and through its own publications, the AGBU branch of Plovdiv has always been a participant in the global diaspora's initiatives. It focuses on events and developments taking place in Turkey, and cooperates with groups such as the Hrant Dink Foundation and DurDe Platform. The Turkish element is a constant because Turkey is the ultimate destination for all messages related to the struggle for recognition of the Genocide. In issue 151 of Parekordzagani Tzain, published in April 2015, the front page of the newspaper has a black background with the words (interestingly, in English), "Recognize the Armenian Genocide. 24 April 2015." A Turkish flag appears inside the "o" of Recognize.

In the weeks before and after the hundredth anniversary, Parekordzagani Tzain devoted special attention to how the anniversary was being observed in Istanbul. Importantly, a delegation from AGBU Europe (which has its main seat

61 Levon Boyajian and Haigaz Grigorian, "Psychosocial Sequelae of the Armenian Genocide," in The Armenian Genocide in Perspective, ed. Richard G. Hovannisian (New Brunswick: Transaction Books, 1986), 183. 
in Brussels), together with the anti-racist movement EGAM and many other organizations, attended a commemoration in Istanbul. AGBU encouraged young Armenians from around the world to be present and join other members of the diaspora in that city, to share the important day of remembrance with its residents. ${ }^{62}$ In Turkey's largest city, a huge march paraded from Istiklal Caddesi to Taksim Square. Early in the day, an event took place in front of the old Haydarpaşa Train Station, from which the first trains transporting the Armenian intellectuals left for Anatolia in 1915.

The fate of the Turkish-Armenian journalist Hrant Dink is a recurrent theme in the pages of Parekordzagani Tzain. Dink was a fundamental figure in the battle for recognition of the historical truth of the Genocide. He was assassinated in front of the building of the Armenian newspaper Agos in Istanbul in January 2007. The diaspora associates his memory with a "new Armenian martyrdom." AGBU Plovdiv has collected and published a Bulgarian translation of his writings, which has contributed to making Dink's work known to the wider Bulgarian population. ${ }^{63}$

In a certain sense, Armenians and Bulgarians are allies in terms of their confrontation with the Ottoman past, as well as in their relationship with present-day Turkey. The attitude of Bulgarian Armenians towards Turkey is complex and somewhat contradictory. For example, many Armenians in Plovdiv can still speak the Turkish language, which has been handed down to them by the generation that survived the genocide. ${ }^{64}$ Very often, if we look beneath the surface of suffering and prejudice, we find a living heritage of elements of Turkish culture, which in some ways (in food, in music, etc.) are similar to those of the Armenian diaspora itself. However, Armenians are unwilling to admit too much (or too openly) to their relationship to the Turkish world and a common cultural past. There is still a sense of threat that dominates the psyche of the nation in the diaspora. Until the issue of recognition of the Genocide is solved, Armenian suspicions of the Turks will be passed on to future generations and affirmed in a variety of ways.

62 "1915-2015: Turks, Armenians, Europeans: Let's Commemorate the Armenian Genocide Together in Turkey," https://www.remember24april1915.eu/.

63 In 2011, AGBU's publishing house published the book Two Close Peoples, Two Distant Neighbors (in Bulgarian Dva blizki naroda, dva dalechni sŭseda Armeniia - Turtsiia). The book contains a selection of Hrant Dink's articles from the newspaper Agos. Hrant Dink, Dva blizki naroda, dva dalechni sŭseda Armeniia - Turtsiia (Plovdiv: Armen Tur, 2011). A second volume of Dink's writings will appear in the near future.

64 See Mitseva, Armentsite v Bŭlgariia, 153. 


\section{The Role of Monuments in the Construction of Memorial Spaces}

Armenian cultural and social events, and the articles in the pages of books and newspapers, could not perpetuate the memory of the Genocide were they not supported by specific visual and physical features of the landscape. These "monumental sites" bring the Armenian Genocide and its victims directly to the observer's attention and are an important setting for the transmission of "postmemory." In 2005, coinciding with the ninetieth anniversary of the beginning of the Genocide, the AGBU branch in Plovdiv erected a monument to the victims of 1915. It also established a small museum dedicated to the Armenians and the Genocide in the crypt of the apostolic church. In the old Armenian tradition, the monument took the shape of a large wooden khachkar, inspired by a similar one in Paris. Khachkar in Armenian translates literally as "cross stone." The khachkar is one of the earliest manifestations of the Christian religiosity of the Armenian people. ${ }^{65}$ Such monuments are particularly significant for Armenian culture, because they were erected throughout the historical Armenian territories. Unfortunately, in recent years serious damage has been done to the important historical monuments in the Caucasus. In the late 1990s and early 2000s, numerous old khachkars and tombstones were destroyed in the town of Julfa in Azerbaijan, symbolically removing the last trace of Armenian history from the Nakhichevan exclave. ${ }^{66}$

The declared purpose of erecting a khachkar in Plovdiv was to contribute to the struggle for recognition of the genocide of the Armenian people everywhere in the world. ${ }^{67}$ The khachkar was produced in the Armenian city of Vagharshapat (Etchmiadzin), home to the Catholicos, the spiritual leader of the Armenian Church. It was then transported to Plovdiv. On April 24, 2005, the cross was inaugurated in the heart of Plovdiv's Armenian community, between the school and the church.

Plovdiv's khachkar is perhaps the most salient manifestation of the Armenian presence in the city. On its pedestal we can read, in both Bulgarian and Armenian: "In memory of the 1,500,000 Armenian victims of the first genocide of the twentieth century, organized and implemented by the leaders of the power of

65 Giulio Ieni, "Le arti figurative ed i khatchkar," in Gli armeni, Adriano Alpago Novello et al. (Milano: Jaca Book, 1985), 261.

66 Krikor Maksoudian, History of the Armenian Alphabet and Literature (New York: St. Vartan Press, 2006), 129.

67 "Izgrazhdane na memorialen kompleks v pamet na zhertvite ot genotsida," Parekordzagani Tzain, No. 4 (December 2004), 5. 
young Turks in 1915." On the wall to the left of the monument, we find a marble slab engraved with the same sentence in English, and a second one in Bulgarian, which states that the khachkar was made possible thanks to gifts from members of the Armenian diaspora in Paris and New York, a major donor from Plovdiv, and the entire Armenian community of Plovdiv. The inscription confirms the cohesion of the local community as well as its cooperation with the diaspora abroad in initiatives to preserve the memory of the Genocide. Some Armenians, including a Plovdiv poet and writer, Hovannes Mikaelian, have expressed an intention to erect another important landmark in the city, also dedicated to the memory of the Armenian genocide and inscribed in both Armenian and Bulgarian. ${ }^{6}$ In his book, What I Want to Say, Mikaelian writes:

For a long time the idea of a monument to my predecessors, the victims of the genocide was growing inside of me.... The idea was to install a simple symbolic monument in an adequate place in the city, which would remind future generations of the worthy honor of the Armenian people.... Bulgaria was the most hospitable country for Armenian refugees at the time. That is why grateful Armenians want the erection of a symbolic monument.... ${ }^{69}$

The presence of monuments in the public space is particularly important to a community that still lives very much in the past; such a nation needs symbols to pass on values and memories so that no one may forget. Above all, the monuments support the cause of gaining recognition of the Genocide by other nations. To inscribe a space, to mark it with powerful symbols, is an action that invests the space with a mnemonic function; the monumental space exists in order to affirm and remember who the Armenians are, what their past is, and what they suffered. In that way, postmemory is transmitted to future generations and is re-signified. ${ }^{70}$

Another monument to the memory of the genocide is located in the Armenian cemetery of the city, which forms part of the city's main graveyard. That monument has several plates on its base with inscriptions in the Armenian

68 Hovannes (Oncho) Mikaelian, interview with author, October 2010.

69 Hovannes Mikaelian, Tova koeto iskam da kazha za... (Plovdiv: Matador 74, 2010), 47-49. Author's translation - G. S.

70 Armenians are acutely aware of the importance that inscribing a space has for the perpetuation of collective memory. A significant example is the stele located in the Armenian capital Yerevan, on which the names of the victims of the massacres are carved, together with the names of world personalities who have recognized those crimes as genocide. See the article by Professor Agop Ormandjian that appeared in Parekordzagani Tzain, No. 17 (January 2006), 10. 
language, one of which is a poem by Silva Kaputikian, a famous Armenian poet. Another plate bears the names of the Anatolian cities where thousands of Armenians were annihilated, such as Urfa and Muş. On the fourth side of the monument's base is a plate which states, in Bulgarian: "In memory of the one and a half million innocent Armenians from Western Armenia and Turkey who died on the path of forced exile because of the barbarous persecutions from 1915 to $1918 . "$

In a certain sense, the monuments erected in the Armenian neighborhoods in the city of Plovdiv, and elsewhere in the world, are a necessary "counterweight" to the disappearance and abandonment of cultural monuments in the historical territory of Western Armenia. The lost monuments there embodied the "fragments of an ancient and abruptly interrupted history." A journey through the ancient Armenian lands in Turkey is unavoidably a "journey into the void, in a disputed and elusive memory, in the awareness of the tragedy." 71 In the absence of any possibility of going back to the old territories to reclaim their cultural history, Armenians have a need to mark the public spaces in their adoptive homelands around the world with monuments dedicated to their own past, as a symbolic way of affirming their presence to every observer. The Plovdiv cemetery is an appropriate place to reflect on the individual and collective memory of the genocide. The graves of the community's ancestors represent a history that cannot be forgotten, as most of the people buried there were genocide survivors or were descended from those who had to abandon their homeland forever. Their memories in fact consecrate the cemetery and each individual grave contributes to the holiness of the place. Individual grief for the loss of deceased loved ones combines with the collective suffering embodied in the monument of the Genocide, which every Armenian in Plovdiv recognizes is part of himself or herself.

\section{The "Small Museum" of the Genocide in the Crypt of the Church}

As previously mentioned, besides the khachkar, another important "mnemonic" installation was built in Plovdiv in 2005, on the occasion of the ninetieth anniversary of the Genocide. The community created the so-called "small museum" of the Genocide, dedicated to all victims of that tragedy. This museum is quite relevant to our discussion on the role of symbols and visible

71 See Aldo Ferrari, "Van: il Paradiso Perduto degli Armeni," in "A mari usque ad mare." Cultura visuale e materiale dall'Adriatico all'India. Scritti in memoria di Gianclaudio Macchiarella, eds. Mattia Guidetti and Sara Mondini (Venezia: Edizioni Ca'Foscari, 2006), 332, doi: 10.14277/97888-6969-085-3. 
objects in creating spaces of memory. The museum is located in the crypt of Plovdiv's Armenian Church and displays numerous artifacts and relics from the old Armenian territories. These include personal items, books, photos, official documents that people fleeing the massacres managed to take away with them. Their descendants donated the objects to the museum to contribute to collective remembrance. The small museum is an important place where the interior and exterior spaces of memory fuse, and it is important as well to the self-image of the community. In order to speak to future generations, memories need specific, tangible anchor points. ${ }^{72}$ These are chiefly places and objects in which, by virtue of their common symbolic frame, a group is able to root its existence. ${ }^{73}$ The museum was established by the voluntary participation of the community's members, who donated their family heirlooms for the sake of collective memory. In a long message published in Parekordzagani Tzain, the council of the Armenian Church addressed all Armenian citizens who had preserved photos, objects or documents regarding the tragic events. It encouraged them to offer their material to the museum and thereby do their part to preserve the memory of the Genocide. ${ }^{74}$ The museum was, similarly to the other cases here discussed, an initiative that allowed the emergence of new practices of postmemory, which were capable of reintegrating the dualism between the individual and the collective.

The museum is a place where Armenian identity stands out in relief against the background of an extremely tragic history. One cannot help noticing the strength of a cultural tradition that has been physically preserved by virtue of the survival of its strongest symbols: manuscripts, books, crosses, and religious paintings. Some of the museum's exhibits are church relics that were smuggled out of the Ottoman territories during the Genocide and brought to Plovdiv. These objects are tangible survivors of the genocide with which people can identify and empathize. The objects are not inanimate, ${ }^{75}$ on the contrary, they are full of life and hope, and have become talismans and metaphors for the survival of the Armenian people.

The persistence of the memory of the Genocide among the diaspora community is strongly dependent on the use of objects that form part of a mythologized symbolic narrative. They transmit both personal and social values. They

72 Eviatar Zerubavel, Time Maps: Collective Memory and the Social Shape of the Past (Chicago: University of Chicago Press, 2003), 82.

73 Ugo Fabietti, L'identità etnica. Storia di un concetto equivoco (Roma: Carocci, 1995), 151.

74 Rupen Tchavushian (head of the AGBU Plovdiv), interview with author, autumn 2010.

75 Remo Badei, La vita delle cose (Roma: Laterza, 2009). 
have absorbed the emotions, thoughts and sensations of their former owners. They seem to be waiting for someone to give them back their voice, especially the new "generations of postmemory."

\section{The Relationship of the Post-Genocide Diaspora with the Lost Territories}

The word diaspora (spyurk in Armenian) derives etymologically from the Greek word diaspéiro, "to disseminate." The term connotes the idea of an original place from which the dispersion took place and evokes images of travel and removal. Associated mainly with the destinies of Armenians and Jews, the word has also acquired a traumatic connotation when applied to people expelled from their original territory, especially where their numbers outside the borders of their motherland exceed those of its present-day inhabitants. There are now about seven million Armenians in the world (three million of whom live in today's Armenia). The dispersion of the Armenian people resulted from instability in the old Armenian motherland since ancient times, stemming from political strife, conquest, religious persecution, massacres and deportations. ${ }^{76}$

The discourse of the Armenian diaspora has focused for many years on "impermanence." From that perspective, life in a foreign country was a provisional phase before the longed-for return to the motherland. While they waited, Armenians commited themselves in various ways to supporting their community's identity and survival. This imperative emerged after the Genocide and has filtered into the discourses and ideologies of some political parties in the Armenians' new homelands. ${ }^{77}$ To a certain extent, the myth of the return has provided a source of hope and a sense of destiny to the diaspora, as well as an ideological justification for its institutional structures. Despite the fall of the Soviet Union and the creation of an independent Armenia, however, Armenians did not come from around the world to settle in the new country. On the contrary, many people left the newly independent Armenia to live somewhere else. Some of them arrived in Bulgaria, in a process that has not yet stopped.

76 See Boghos Levon Zekiyan: "In our opinion, we can only talk of a diaspora in the strict sense, that is, a state of 'dispersion,' starting with the aftermath of the 1915 massacre .... For the period prior to 1915 it would be more appropriate to talk about 'colonies' .... A large part of the Armenian people still lived on their territories." In Boghos Levon Zekiyan, L'Armenia e gli armeni. Polis lacerata e patria spirituale: la sfida di una sopravvivenza (Milano: Guerini e Associati, 2000), 143. Author's translation - G. S.

77 Denise Aghanian, The Armenian Diaspora: Cohesion and Fracture (Lanham: University Press of America, 2007), 118. 
When Diaspora Armenians speak about a return to their homeland, they are in fact engaged in a process of "double imagination." 78 The majority of Armenians have their genetic roots in the Western Armenia of the Ottoman Empire, where their ancestors were living until the Genocide. As a consequence, their "true homeland" is located in Anatolia, ${ }^{79}$ to which it would be quite difficult to return. Instead, some Diaspora Armenians who are descendants of people who escaped the Genocide travel to the Republic of Armenia. They experience their journey as a kind of pilgrimage, a symbolic rapprochement with their "imaginary homeland."

The AGBU branch in Plovdiv often publishes articles about travel by Armenian journalists in the historical territories. For example, a column, "A Journey Through Our Ancient Lands," appeared in several issues of the AGBU newspaper in 2015. In this series of articles, the journalists describe the Armenian cultural heritage of cities such as Kars, Diyarbakir and Van. They also refer to the poverty of the region and the conversion of historic Armenian sites into Muslim places. Such is the case in the city of Ani and the Church of Surap Arakelot, which today functions as a mosque. Both are located in the Kars territory of northeastern Turkey. Although they belong to an imaginary geography and history in the minds of Diaspora Armenians, the Turkish territories they inhabited before the genocide have a tangible impact on members of the diaspora and produce real effects. ${ }^{80}$

An example of this in the context of the Armenian community of Plovdiv is the trips organized by associations linked to the Armenian Church to visit Edirne, the first Turkish city over the border with Bulgaria. Many Armenians lived in Edirne or its surroundings even before the time of the Genocide. All the survivors of the Genocide had to pass through the city to reach Bulgaria. ${ }^{81}$ Edirne is a name that very often recurs in the narratives and personal stories of the survivors' descendants. An active group of pensioners shows particular enthusiasm for such trips and travels to Edirne quite often, in spite of the uncomfortable conditions of the journey (in particular, the strict and long

Ibid., 166.

79 Armenians often refer to the concept of "historical Armenia." The current territory of the Republic of Armenia corresponds to only a tenth of Armenia's original extent at the apex of its history.

80 On the practice of "diaspora tourism," see for example Zeynep Turan and Anny Bakalian, "Diaspora Tourism and Identity: Subversion and Consolation in Armenian Pilgrimages to Eastern Turkey," in Diasporas of the Modern Middle East: Contextualising Community, ed. Anthony Gorman and Sossie Kasbarian (Edinburgh: Edinburgh University Press, 2015), 173-211.

81 See the trilogy by the Bulgarian-Armenian writer Sevda Sevan: Rodosto, Rodosto, Niakŭde na Balkanite, Der Zor: Roman-trilogiia (Sofia: Hristo Botev, 1996). 
customs controls at the border). An interesting fact is that some of the elderly descendants of genocide survivors who take part in the trip are trilingual; they are among the very few remaining Armenian people who still speak Turkish in addition to Armenian and Bulgarian, having heard the language spoken at home by their parents or grandparents. This facility is an important element in their practice of memory and "postmemory" and its transmission and elaboration. Their journeys can also be interpreted as a response not only to the history of physical annihilation and violent expulsion from the ancient territories, but also to Turkey's ongoing rejection of any right the survivors and their descendants have to return to their ancient homeland or reclaim confiscated property. The fact that they live so close to the Turkish border (less than two hours away) gives the Plovdiv diaspora a "privileged" position. They are near enough to the Ottoman Empire's successor state to visit, but at the same time they are more acutely exposed to a painful confrontation with the past and the unrelenting denial of the Genocide by many different Turkish actors.

It is a reality, though, that the community also feels a need to move forward. The publisher of the Parekordzagani Tzain newspaper, Hripsime Erniasian, has said in an interview that it is time for the AGBU to focus on new topics and foster a new sense of Armenian identity that is firmly positioned in contemporary times. ${ }^{82}$

\section{Conclusions}

In this paper, I have treated the topic of the commemoration of the Armenian Genocide among the diaspora living in the Bulgarian city of Plovdiv as a phenomenon that involves the very strong intergenerational transmission of a traumatic memory. I have demonstrated that the tragic events that took place in the Armenian territories under the last years of the Ottoman Empire still exert a great influence over the life of the Armenian community of Plovdiv and its relationship with Turkey. There is an undeniable "presence of the past," and the community's core values are based on the preservation of its ethnic memory and identity. This is particularly evident in social and cultural initiatives commemorating the Genocide that are organized and carried out by the main local actor of the diaspora, the AGBU. The AGBU and the Armenian community as a whole host a specific will to preserve the fundamental characteristics that are the substance of their "Armenianness" across various temporal and spatial dimensions.

82 Hripsime Erniasian, interview with author at the Parekordzagani Tzain offices, May 2018. 
Their identitarian commitments are closely connected with the memory of the Genocide, on which the Armenian diaspora is ontologically dependent.

Through my analysis of the public spaces and revered objects of the community, I have shown that, for the Armenian community of Plovdiv, its collective memory of the Genocide is constructed in relation to particular spaces - "places of memory" - as well as objects that inspire reflection on the past. These places and objects anchor the Armenian identity at a specific point in its past. The relevant spaces in Plovdiv are public, such as cemeteries, museums, and even the press (the Parekordzagani Tzain newspaper). The objects are of a most disparate nature, including monuments, graves, and pictures. Objects and monuments have an explicit symbolic function. They play an active role in the mnemonic process and relate to a memory of the Genocide that is experienced both privately (through individual and family forms of "postmemory") and collectively (in symbolic and institutional commemoration practices by the members of the community). In the discourse on the memory of the Genocide and in its commemoration, the individual and society are inextricably bound up and dependent on one another. The symbols of martyrdom and of the lost ancestral homeland are visible and are clear to everyone in their meaning, but they are also experienced subjectively by those who behold them. Consequently, the tragic story of the Armenian genocide is remembered and fosters the internal cohesion of the community's members. It encourages further manifestations of "postmemory."

Because most of the Armenian diaspora of Plovdiv is descended from genocide survivors, all members of the community are still personally touched by the massacres that took place in the Ottoman Empire early in the twentieth century. Almost everyone has a personal family story to tell related to the tragic events. The Genocide is the experience that unites all Armenians, and its commemoration is a way to manifest the miracle of the nation's survival notwithstanding its dispersion around the world and the definitive loss of its ancestral homeland. As it was written on the occasion of the seventieth anniversary of the genocide: "by a continued denial by the Turks of the genocide and by the general lack of knowledge and acceptance of the truth...the psychological genocide continues. As a consequence, generations of Armenians are unwilling and unable to put aside the events of 1915 as past history." 83

83 Boyajian and Grigorian, "Psychosocial Sequelae of the Armenian Genocide," 183. 